\title{
REFLECTIONS
}

\section{A Journey to Someplace Better}

\author{
Jobn J. Frey III, MD \\ Department of Family Medicine, University of Wisconsin Medical School, Madison, Wisc \\ Ann Fam Med 2003;1:175-176. DOI: 10.1370/afm.28.
}

$\mathrm{O}$

ur practice is one of two in a community

where many of us speak Spanish. The data

from the 2000 census showed a $500 \%$ increase

in the Hispanic population in our county. Some days it seems as though most of them find their way to our practice. One census map shows the counties in the United States with Latino populations of higher than $20 \%$, and other than the obvious border counties of the Southwest and such places as Florida and New York, counties with large Latino populations are scattered right across the Great Plains from Ohio to Kansas and, in recent years, down into the Middle Atlantic states. Fluency in Spanish is more than a nice addition to a residency applicant's curriculum vitae; it gets extra points come time for the match.

Many young men whose jobs entail heavy manual labor in our county come to see me, and young women working in laundries and cleaning services see my female partners. The children see us all, accompanied by whoever is at home and able to take them to the doctor for illness visits or checkups. The staff has been at the clinic for decades and, in response to our changing population, has made valiant but frustrating attempts to learn basic Spanish. We all struggle to find words for bowel movements, impotence, anxiety, and depression that are not in the Spanish textbooks. I am forever running to find my partner who grew up in Mexico, asking her about words in Spanish I cannot seem to find or my patients do not seem to understand. She always smiles and shakes her head a bit when she tells me the correct way to phrase things.

During a busy clinic morning, I glanced at my

Conflicts of interest: none reported

\section{CORRESPONDING AUTHOR}

John J. Frey III, MD

Department of Family Medicine

University of Wisconsin Medical School,

777 S Mills St

Madison, WI 53715

jfrey@fammed.wisc.edu schedule and saw names of patients I did not recognize, one of whom was a 9-year-old girl for a wellchild examination for school. Because it was early summer, I assumed that she was just getting her checkup early to avoid the end-of-summer rush. Her name was Carolina.

I came into the examination room and saw her sitting in the chair next to her mother, a pleasant woman whom I had never met either. Carolina was sitting in a way that immediately caught my eye-like the little girl in a Norman Rockwell painting-long dress, hands folded together on her knees, her back upright against the back of the chair, making direct eye contact with me, a smile on her face. She seemed happy to be there, not the case with most 9-year-olds dragged by a parent to the clinic for a camp or school physical examination. (I have seen bemused interest on their faces, but not delight.) Her mother, after a quick glance at me and a polite hello, turned to look at Carolina with a glance almost of adoration. As I started asking questions, Carolina gave me most of the answers, except, of course, her early childhood illnesses. "I am here to get permission to go to school," she said. "She needs to get the vaccinations," her mother filled in. In addition to her immunizations, she needed some dental work, needed to eat a bit better, and had a long way to go to learn English.

"Well, where are you going to school," I asked. "I don't know," she answered, "I just arrived here." I asked her mother when they had come to the United States, and her mother said that she had been here 2 years, but that Carolina came last week.

"How did you get here?" I inquired, attempting to make small talk. "I came in the van," she answered, "last month, from Mexico, from my home in Morelos. I left our home town and went on a van to Mexico City, where I stayed for a while with some people, then we got on a bus and drove for a long time. When we got to a town, some of the people left for the mountains, and all of the rest of us stayed in a big room where there were police. After a while, they let me go and I got on another van and we came into the United States 
to a very big city. Then I got on another van and came here to be with my parents."

"Who did you come with?" I asked. "I came by myself, in the van with some other people," she replied. She smiled and looked at her mother, who in turn continued to gaze, lovingly, at her daughter. Nine years old, more than 3,000 miles, by herself.

I have learned from my patients during these years in practice that many men, mostly by themselves, but at other times with their wives, leave rural Mexico for places like our community because the word has gotten back to their hometowns that there are opportunities here for jobs. I always imagine signs in little towns scattered throughout Mexico and Central America that read, "Good jobs in Madison" (or Dodge City or Cedar Rapids or Springfield), with a contact and a telephone number that starts someone thinking, "I could go there and do better."

The jobs make it possible to send money home to help improve the lives of their families, a story much like that of other groups which populated the history of our part of America. The names of little towns throughout Wisconsin proclaim which immigrant group settled there first - New Lisbon, New London, New Holstein, New Berlin, Germantown, Wales, Belgium. After the couples from Morelos or Oaxaca or Puebla feel that their jobs and lives are secure, they bring their children from Mexico. In bringing them, parents separate their children not only from friends and family but from all the familiar things of their children's lives and culture. The parents believe that, after a while, life will be better here and that their children will recover from the grief of lost homelands, will find friends, schools, a life. For the parents, the alternative of having their children raised 3,000 miles away by relatives is too much to bear. They need the reasons they work 2 jobs and live in small apartments right in front of their eyes to help them keep going.

I knew why Carolina's mother looked at her with such love. Her parents must have been frantic with fear, worrying and listening for her progress through towns and across borders, and then feeling the elation as she, the reason for their 2 jobs and long days, arrived in town. Ships sink, vans crash, people get arrested, get quarantined, get locked and smothered in trucks, or die of starvation. Sometimes they make it. Carolina's persistence in the face of such danger might have been because she was a child, too inexperienced to know any better. But I would like to believe it could also be her courage, trusting that her family sent her on a journey to someplace better, ignoring the evil that can, at times, seem to be everywhere, having faith that someone would care for her. Now she was here, safe, with her family, seeing a doctor, and getting ready for the next adventure.

The times here, too, are hard and getting harder. William Carlos Williams called the 1930s "the knife of the times that kills men's souls," and just under the surface of our patient's lives, that knife is pressing. Jobs are fewer and more demanding. Joblessness is real and growing, even in seemingly recession-proof cities like Madison. I worry that Carolina's family will be forced to make the long trip back to Morelos out of necessity rather than choice. I would be robbed of her presence, and I need it. When my world, on occasion, seems full of patients and friends who feel hopeless and too tired to continue, I imagine Carolina, hands firmly on her knees, riding a van, looking out the window at a world she has never seen toward a place she could only imagine. It is the image I need to make it through days when, sometimes, it feels as if all I see is despair - a solitary 9-year-old girl, full of hope and dreams, with a belief in guardian angels and in friendly, rather than threatening, strangers.

I asked Carolina what she was going to do after she went home. "Get ready," she said. "Next week I go to school."

To read commentaries or to post a response to this article, see the online version at http://annfammed/cgi/content/full/1/3/175.

Key words: Physician-patient relations; Hispanic Americans; family practice; cross-cultural comparisons

Submitted February 7, 2003; submitted, revised, April 17, 2003; accepted April 21, 2003.

Acknowledgments

For Richard Anstett 